CZASOPISMO INŻYNIERII LADDOWEJ, ŚRODOWISKA I ARCHITEKTURY

Mateusz RAJCHEL ${ }^{1}$

Tomasz SIWOWSKI ${ }^{2}$

\title{
RESEARCH ON THE HYBRID FRP COMPOSITE - CONCRETE BRIDGE GIRDER
}

\begin{abstract}
The hybrid bridges are composed of FRP composites and concrete, in which FRP girders work compositely with $\mathrm{RC}$ deck slab. The hybrid bridge can be characterized by, among others, high stiffness and strength, excellent durability and thus low life cycle costs. Recently several HB have been built in Spain and USA. The construction of the first Polish innovative road hybrid bridge is planned as a part of the R\&D project ComBridge. It will also be one of the largest (in terms of span length) of this kind in the world. The bridge will be built of FRP box girders made by infusion process and lightweight concrete deck slab reinforced with GFRP bars. The slab will be connected with the girders with special kind of shear studs and adhesive. The Rzeszow University of Technology (RUT) as the research partner in $\mathrm{R} \& \mathrm{D}$ project is responsible for structural testing of girder-slab connections, GFRP reinforced concrete slab and the full hybrid FRP/RC girder in full scale in the laboratory. After the bridge is built the RUT will carry out the proof test of the completed structure. The aim of the paper is to describe static tests of the full-scale hybrid FRP/RC girder and to present testing results in terms of its general behavior, carrying capacity, failure modes and FEM model validation.
\end{abstract}

Keywords: FRP composite girder, lightweight concrete slab, GFRP reinforced concrete, hybrid FRP/RC bridge, static full-scale test.

\section{Introduction}

A major concern for many bridge superstructures (decks/beams) is the significant reduction in durability and life expectancy caused by the corrosion of the reinforcing steel and the corresponding deterioration of the concrete. As one of the solutions to this problem, structural applications of fiber reinforced polymer (FRP) composites have recently been attractive in the civil en-

\footnotetext{
${ }^{1}$ Author for correspondence: Mateusz Rajchel, Rzeszow University of Technology, Faculty of Civil and Environmental Engineering and Architecture, mrajchel @prz.edu.pl

2 Tomasz Siwowski, Rzeszow University of Technology, Faculty of Civil and Environmental Engineering and Architecture, siwowski@prz.edu.pl
} 
gineering community due to their superior material properties such as high specific strength, and high corrosion resistance, excellent durability, low cycle costs [6]. To make the best use of materials, combinations of FRP and conventional materials have recently been investigated by a number of researchers. According to Mirmiran [5], the most effective use of FRP composites in civil structural applications is in the form of a hybrid construction with concrete. Hillman and Murray [4] proposed the innovative idea of a hybrid FRP-concrete structural system for flexural members, which led to the concept of hybrid beam (HB). Deskovic et al. [3] investigated the short-term behavior of hybrid FRPconcrete beams. Van Erp [8] proposed hybrid FRP-concrete beams for bridge applications. The weight of the hybrid beam was about one-third that of the corresponding concrete beam. The proposed structural type was a box section. A layer of concrete was placed on top of GFRP box in the compressive zone of the section. Kitane and Aref [7] proposed a basic concept of a hybrid FRPconcrete bridge superstructure. The proposed structural type was comprised of trapezoidal box sections. Kitane et al. concluded that the hybrid FRPconcrete bridge superstructure is highly feasible from a structural engineering point of view.

Concrete has good compressive strength combined with relatively low cost, whereas FRP has high tensile strength but relatively high cost. The hybrid FRP - concrete bridge superstructure systems are intended to have durable, structurally sound, and cost effective hybrid system that will take full advantage of the inherent and complementary properties of FRP materials and concrete. The development of a hybrid system that combines FRP composites with conventional materials provides a solution to reduce the initial cost, simultaneously providing a challenge for the design of such systems. Final construction costs can be even lower than conventional materials if such factors as more efficient design, transportation costs and lifting equipment costs are taken into account. The application of hybrid FRP composites could also contribute to a reduction of life cycle costs (LCC) and environmental load. While the initial cost of composite materials is usually higher than alternative construction materials, many life-cycle costs could be eliminated or drastically reduced with the use of FRP composites.

The primary objective of this study was to apply a hybrid FRP-concrete structural system to bridge superstructure systems and verify the viability of the proposed system experimentally and computationally. As a trial case, a prototype bridge superstructure was designed as a simply-supported single span two-lane bridge with a span length of $21.0 \mathrm{~m}$ [9]. A test specimen, fabricated as a full scale model of the prototype bridge girder, was subjected to a series of loading tests: nondestructive tests (flexure, dynamic response, creep, fatigue) and destructive tests (flexure, shear). This paper summarizes the results from the static flexural testing and discusses the performance of the proposed bridge girder. 


\section{Description of the tested FRP/RC girder}

\subsection{Geometry}

The test was carried out on a full-scale FRP/RC hybrid girder with the theoretical span of $21,0 \mathrm{~m}$ and the total length of $22,0 \mathrm{~m}$. The FRP/RC hybrid girder fully reflects the geometry, construction and static scheme of FRP/RC hybrid girder in the real bridge to be built on site. The tested girder consisted of a FRP composite beam with the depth of 1,00 m, which was covered with the concrete deck slab having the thickness of $0,18 \mathrm{~m}$ and the width of 2,48 $\mathrm{m}$. The FRP beam was U-shaped with an open top. The deck slab was reinforced with GFRP bars with a diameter of $12 \mathrm{~mm}$ (Fig.1). The connection of the FRP composite girder and concrete deck slab has been made by means of steel shear studs with M20 thread and epoxy adhesive. The each cross section had four shear studs (two for flange at a spacing of $150 \mathrm{~mm}$ ). Shear studs spacing in longitudinal direction was constant $180 \mathrm{~mm}$.
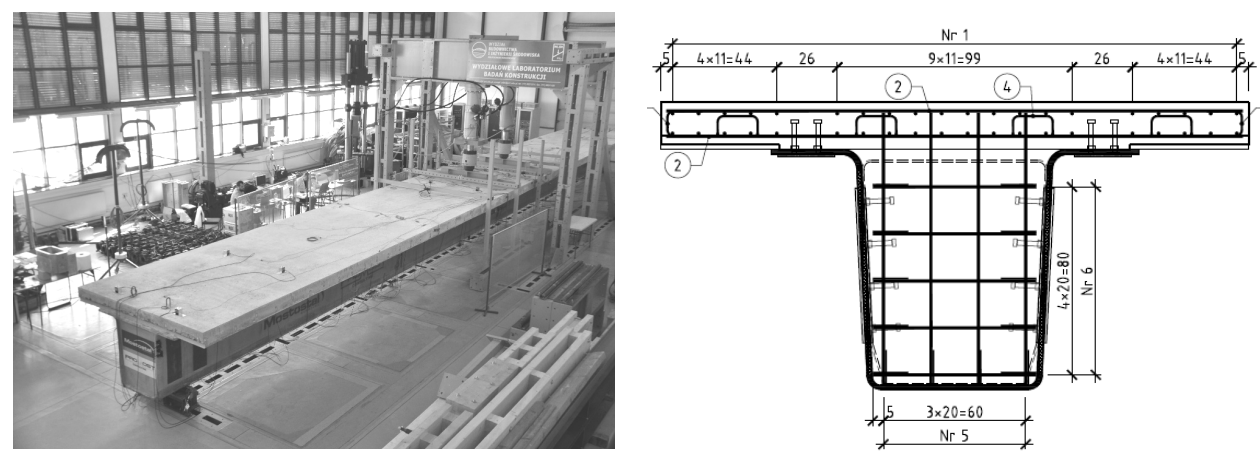

Fig. 1. FRP/RC girder in the laboratory (left) and its cross-section (right)

Rys. 1. Dźwigar FRP/RC w laboratorium (po lewej) i przekrój poprzeczny (po prawej)

\subsection{Materials}

The FRP beam consisted of three basic materials: carbon laminate, glass laminate and a foam. The detailed FRP laminates design was based on the former experience of the RUT gained during realization of the R\&D program on all-composite FRP footbridge [10]. The FRP composite box beam was fabricated with the infusion process using vinylester resin. A uniform thickness of the top flange was $25,2 \mathrm{~mm}$, thickness of the bottom flange was $19,0 \mathrm{~mm}$ and thickness of the webs was $22,6 \mathrm{~mm}$.

The lower flange was made of 28 fiber layers, i.e. 17 layers of carbon fibers with $0^{\circ}$ orientation and 11 layers of E-glass fibers with $\pm 45^{\circ}$ orientation. The top flange was made of 32 layers of E-glass fibers with $0^{\circ}$ and $\pm 45^{\circ}$ orienta- 
tion. Finally the sandwich web was made of 9 layers of E-glass fiber with $\pm 45^{\circ}$ orientation and foam in-between with a thickness of $15 \mathrm{~mm}$. The material constants of basic constituent materials and the strength of the basic component materials (laminates) are established in material tests and are shown in Table 1 and 2 .

Table 1. The material constants (in material axis)

Tabela 1. Stałe materiałowe (w osi materiału)

\begin{tabular}{|c|c|c|c|c|c|c|c|c|c|}
\hline \multirow[t]{3}{*}{$\dot{\mathrm{z}}$} & \multirow{3}{*}{ 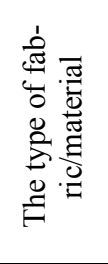 } & \multirow{2}{*}{ 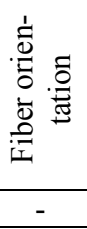 } & \multirow{2}{*}{ 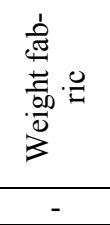 } & \multirow{2}{*}{ 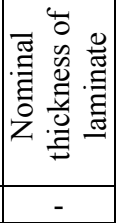 } & \multicolumn{2}{|c|}{ 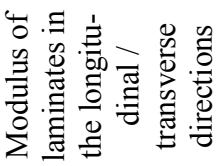 } & \multicolumn{2}{|c|}{ 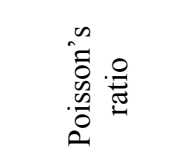 } & \multirow{2}{*}{ 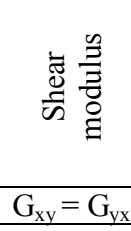 } \\
\hline & & & & & $\mathrm{E}_{\mathrm{x}}$ & $\mathrm{E}_{\mathrm{y}}$ & $v_{x y}$ & $v_{\mathrm{yx}}$ & \\
\hline & & [deg] & {$\left[\mathrm{kN} / \mathrm{m}^{2}\right]$} & {$[\mathrm{mm}]$} & {$[\mathrm{GPa}]$} & {$[\mathrm{GPa}]$} & {$[-]$} & {$[-]$} & [GPa] \\
\hline 1 & Glass & \pm 45 & 1200 & 0,8 & 12,06 & 12,06 & 0,49 & 0,49 & 3,04 \\
\hline 2 & Glass & 0 & 1200 & 0,80 & 42,13 & 10,87 & 0,29 & 0,075 & 2,71 \\
\hline 3 & Carbon & 0 & 600 & 0,60 & 115,76 & 5,72 & 0,41 & 0,021 & 3,32 \\
\hline
\end{tabular}

Table 2. Strength (in material axis)

Tabela 2. Wytrzymałość (w osi materiału)

\begin{tabular}{|c|c|c|c|c|c|c|c|}
\hline \multirow{3}{*}{$\dot{\sim}$} & \multirow{3}{*}{ 离 } & \multirow{3}{*}{ 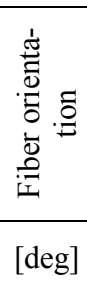 } & \multicolumn{4}{|c|}{ Normal strength } & \multirow{3}{*}{ 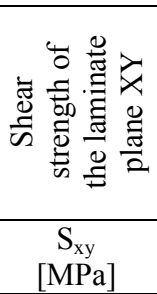 } \\
\hline & & & \multicolumn{2}{|c|}{ 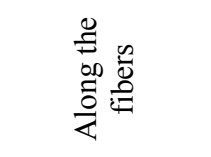 } & \multicolumn{2}{|c|}{ 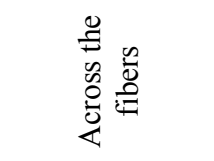 } & \\
\hline & & & $\begin{array}{c}\mathrm{X}_{\mathrm{t}} \\
{[\mathrm{MPa}]}\end{array}$ & $\begin{array}{c}\mathrm{X}_{\mathrm{c}} \\
{[\mathrm{MPa}]}\end{array}$ & $\begin{array}{c}\mathrm{Y}_{\mathrm{t}} \\
{[\mathrm{MPa}]}\end{array}$ & $\begin{array}{c}\mathrm{Y}_{\mathrm{c}} \\
{[\mathrm{MPa}]}\end{array}$ & \\
\hline 1 & Glass $1200 \mathrm{~g} / \mathrm{m}^{2}$ & \pm 45 & 520,0 & 320,0 & 520,0 & 320,0 & 60,0 \\
\hline 2 & Glass $1200 \mathrm{~g} / \mathrm{m}^{2}$ & 0 & 855,0 & 537,0 & 44,0 & 84,0 & 25,0 \\
\hline 3 & Carbon $600 \mathrm{~g} / \mathrm{m}^{2}$ & 0 & 1150,0 & 464,0 & 12,0 & 94,0 & 54,0 \\
\hline
\end{tabular}

Table 3. Orthotropic and isotropic material properties (in material axis)

Tabela 3. Ortotropowe i izotropowe właściwości materiałowe (w osi materiału)

\begin{tabular}{|c|c|c|c|c|c|c|c|}
\hline خ் & 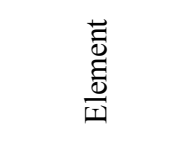 & 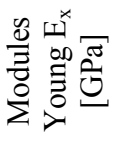 & 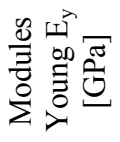 & 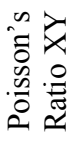 & 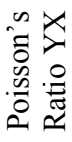 & 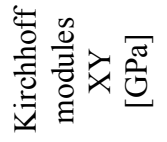 & 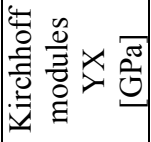 \\
\hline 1 & Top flange & 33,844 & 12,628 & 0,28 & 0,13 & 2,816 & 2,816 \\
\hline 2 & Bottom flange & 77,561 & 9,971 & 0,35 & 0,11 & 3,213 & 3,213 \\
\hline 3 & Webs & 6,194 & 6,194 & 0,01 & 0,01 & 0,928 & 0,928 \\
\hline 4 & $\begin{array}{c}\text { Concrete LC } \\
35 / 38\end{array}$ & 22,38 & - & 0,2 & & & 9,33 \\
\hline 5 & Foam & 0,09 & 0,09 & - & - & - & - \\
\hline 6 & Bars GFRP & 57,8 & - & 0,19 & - & - & - \\
\hline
\end{tabular}


The concrete deck slab was made of lightweight concrete of LC 35/38 class. The real compressive strength of the concrete at the date of testing was 42,1 MPa. The support zones of the FRP beam was also filled with lightweight concrete LC 35/38. Reinforcing GFRP bars were made of glass fibers and polyester resin and have the average tensile strength of $1018,77 \mathrm{MPa}$ and the average elongation at break of $1,92 \%$. The steel shear connectors were designed for a yield strength of $355 \mathrm{MPa}$. Orthotropic and isotropic material properties (in material axis) of all materials used for the girder are shown in Table 3.

\subsection{Design load}

The bridge and its girders were designed to fulfill the requirements of the Polish bridge standard [9]. According to this standard the total weight of the truck to be allowed to pass the bridge is 40 metric tons. For code checking the ULS \& SLS design criteria are based on the CSA Standard [2]. The SLS criterion governed the design and it is based on vertical deflections and natural frequencies limitations of the FRP/RC girder.

\section{The static test program}

\subsection{General description}

The girder was subjected to a comprehensive static tests on the test stand of the accredited laboratory at the RUT (Fig.1). The aim of this study was to assess the behavior of the girder under static load and carrying capacity evaluation, checking of failure modes and validation of FEM model used to design the bridge.

The loading procedure for the girder followed closely the procedure described in the project specifications for the girders used in the actual bridge. The load relevant to calculated inner forces was selected to represent the bending moment and transverse force in phase II (composite cross-section), reflecting characteristic and design load according to the standard used for designing of the bridge (Table 4).

Table 4. The values of the test load

Tabela 4. Wartości obciążeń badawczych

\begin{tabular}{|l|l|}
\hline \multicolumn{2}{|c|}{ Laboratory tests } \\
\hline The design value of internal forces & The value of the test load $(2 \mathrm{P})$ \\
\hline The characteristic bending moment $(1834,0 \mathrm{kNm})$ & $2 \times 195,1=390,2 \mathrm{kN}$ \\
\hline The design bending moment $(2745,0 \mathrm{kNm})$ & $2 \times 292,0=584,0 \mathrm{kN}$ \\
\hline The characteristic transverse force $(405 \mathrm{kN})$ & $2 \times 405,0=810,0 \mathrm{kN}$ \\
\hline The design transverse force $(607,0 \mathrm{kN})$ & $2 \times 607,0=1214,0 \mathrm{kN}$ \\
\hline
\end{tabular}


The static testing had several objectives. The first objective was to determine the ultimate capacity and failure mode of the hybrid girder. The second objective was to determine the level of load and strain associated with the onset of significant damage. This objective was accomplished based on evaluation of the acoustic emission (AE) data.

\subsection{Loading procedure}

The girder was tested in four-point bending using two $630 \mathrm{kN}$ hydraulic actuators mounted on a steel frame. Actuator spacing was 2,2 $\mathrm{m}$ (Fig. 2). The load was distributed on the contact surface $2,50 \times 0,30 \mathrm{~m}$ of the deck slab.

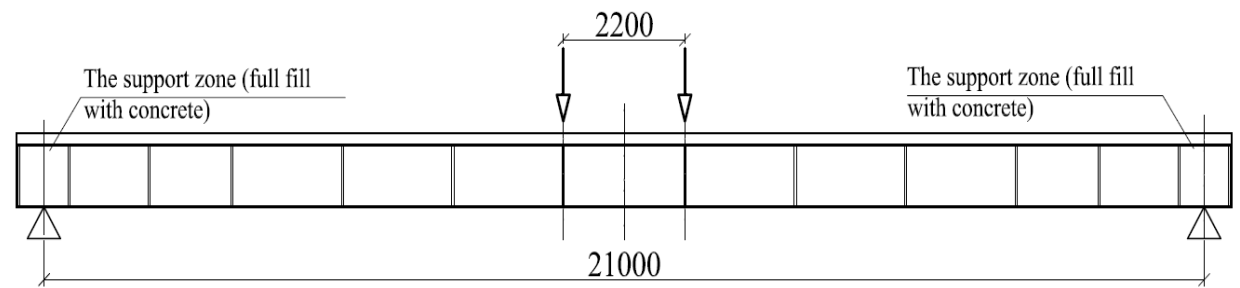

Fig. 2. Loading scheme of the girder

Rys. 2. Schemat obciążenia dźwigara

The girder was loaded statically in five stages with several increasing load levels (Table 3 and Fig.3).

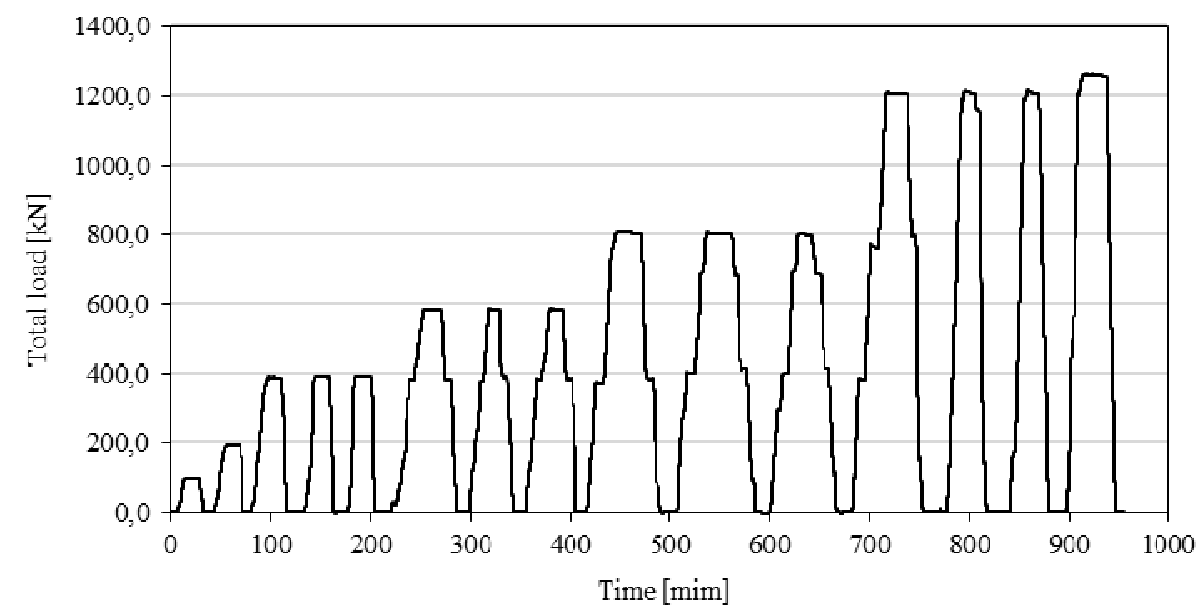

Fig. 3. Loading scheme for static testing of FRP/RC hybrid girder

Rys. 3. Schemat obciążenia w badaniach statycznych hybrydowego dźwigara FRP/RC 
The following stages were used to load the girder up to the border load testing machine actuators equal $1260 \mathrm{kN}$ : the characteristic and design bending moment (total load: $390,2 \mathrm{kN}$ and $584,0 \mathrm{kN}$, respectively) and the characteristic and design transverse force (total load: $810,0 \mathrm{kN}$ and $1014,0 \mathrm{kN}$, respectively). About 15 minute load holds were used for intermediate load steps and $30 \mathrm{~min}$ load hold was used at each peak load. The purpose of load hold periods is to reduce non-genuine $\mathrm{AE}$ data and facilitate the damage, if any.

\subsection{Instrumentation}

The 46 electrical resistance gauges were used for strain measurement: 11 strain gauges on the bottom flange, 6 on the top flange, 2 square rosettes on the web, 4 strain gauges on the shear studs and 13 gauges on the concrete slab deck. Displacements were recorded with 18 transducers along the length of the girder and at bearing pad location. Figs 4 and 5 show the location of the strain gauges and displacement transducers in the middle section of the girder, on the deck slab and the bottom flange. Calibrated load cells were used to monitor the load. Load, strain, and displacement data were recorded one every second during testing with a digital data acquisition system. AE data was also recorded continuously with 92 channel monitoring system. Since any considerable failure during static test was not be seen, the determination of internal damages in the FRP composite beam was mainly based on the AE data. The AE measurement and its results are out of the scope of this paper.
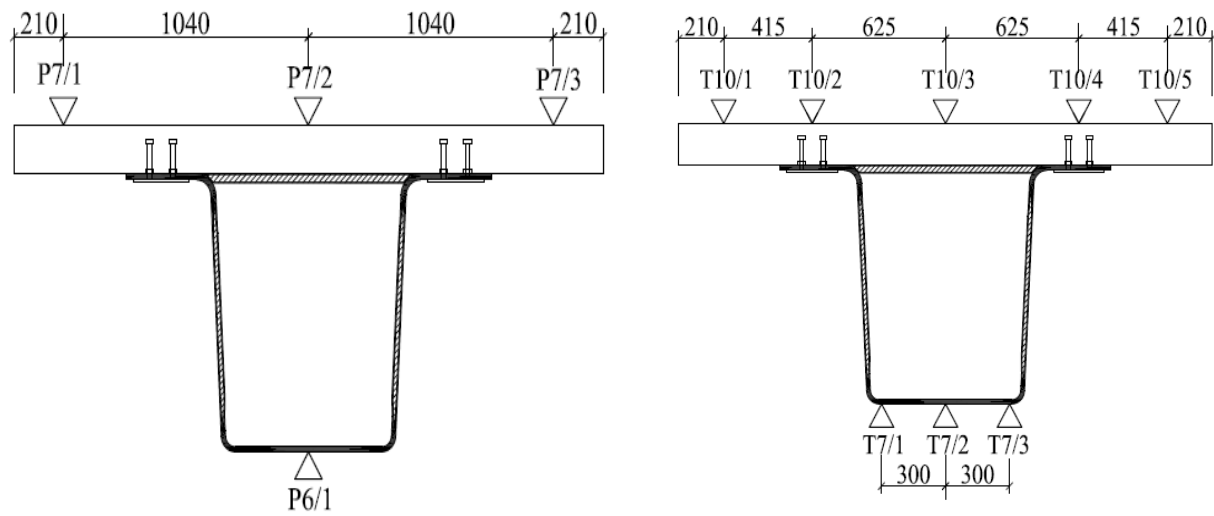

Fig. 4. Instrumentation layout for FRP/RC hybrid girder in the mid span: $\mathrm{P}$ - displacement transducers (left), $\mathrm{T}$ - strain gauges (right)

Rys. 4. Rozmieszczenie czujników w środku rozpiętości hybrydowego dźwigara FRP/RC: $\mathrm{P}$ - czujnik przemieszczeń (po lewej), T - mierniki odkształceń (po prawej) 

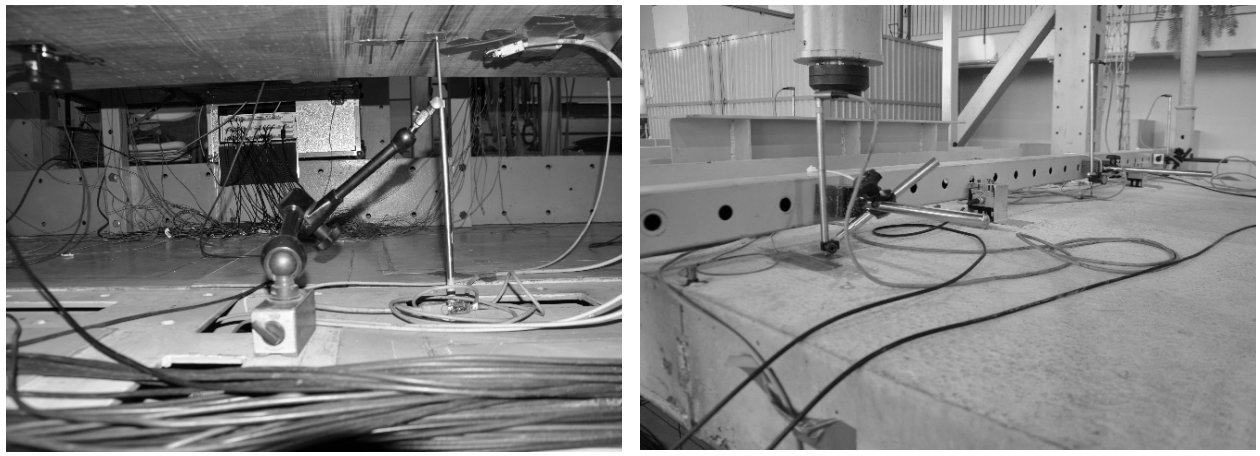

Fig. 5. Displacement transducers under the bottom flange (left) and on the deck slab (right) Rys. 5. Czujniki przemieszczeń pod pasem dolnym (po lewej) i na płycie pomostu (po prawej)

\section{Experiment results}

On the following figures the main testing results regarding strains and displacement are presented. Only the last load stage $(0-1260 \mathrm{kN})$ results are shown reflecting the total linear behavior of the girder in the whole scope of loading. Figure 6 shows the displacement plot in the measuring point located on the deck slab in the middle of the girder for the last load cycle $(0-1260 \mathrm{kN})$. Figures 7 and 8 show the strain plots in the measuring points located on the deck slab and bottom flange in the middle span of the girder.

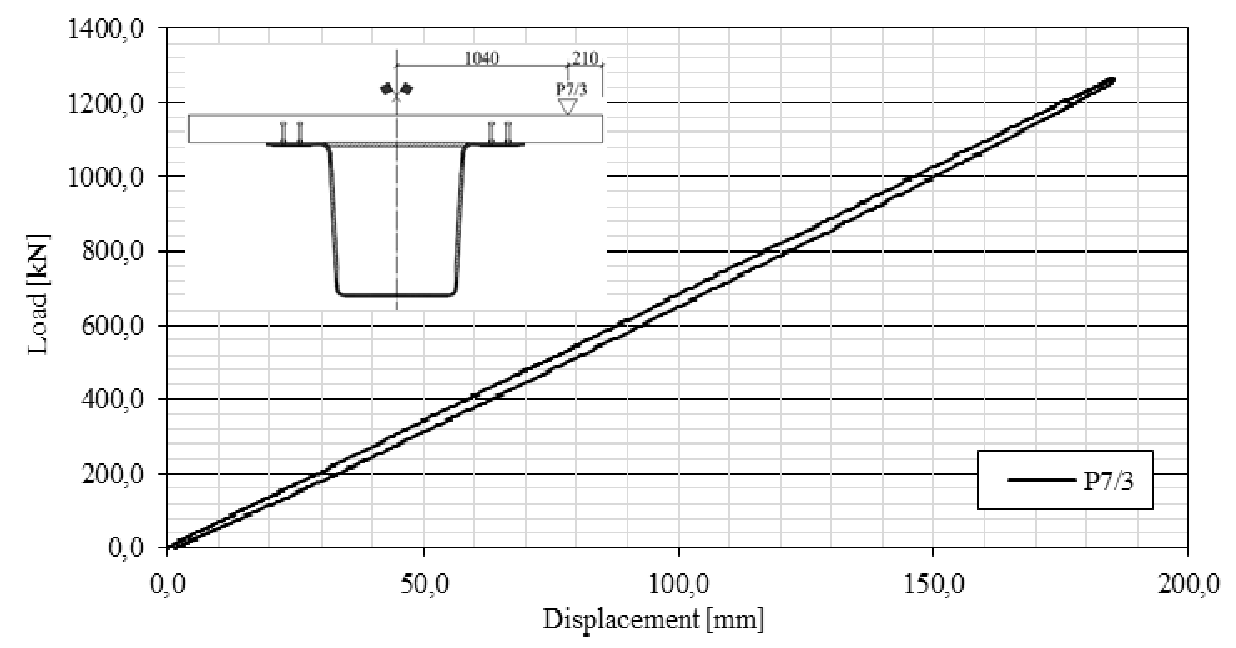

Fig.6. Mid-span displacement plot

Rys. 6. Wykres przemieszczeń w środku rozpiętości 


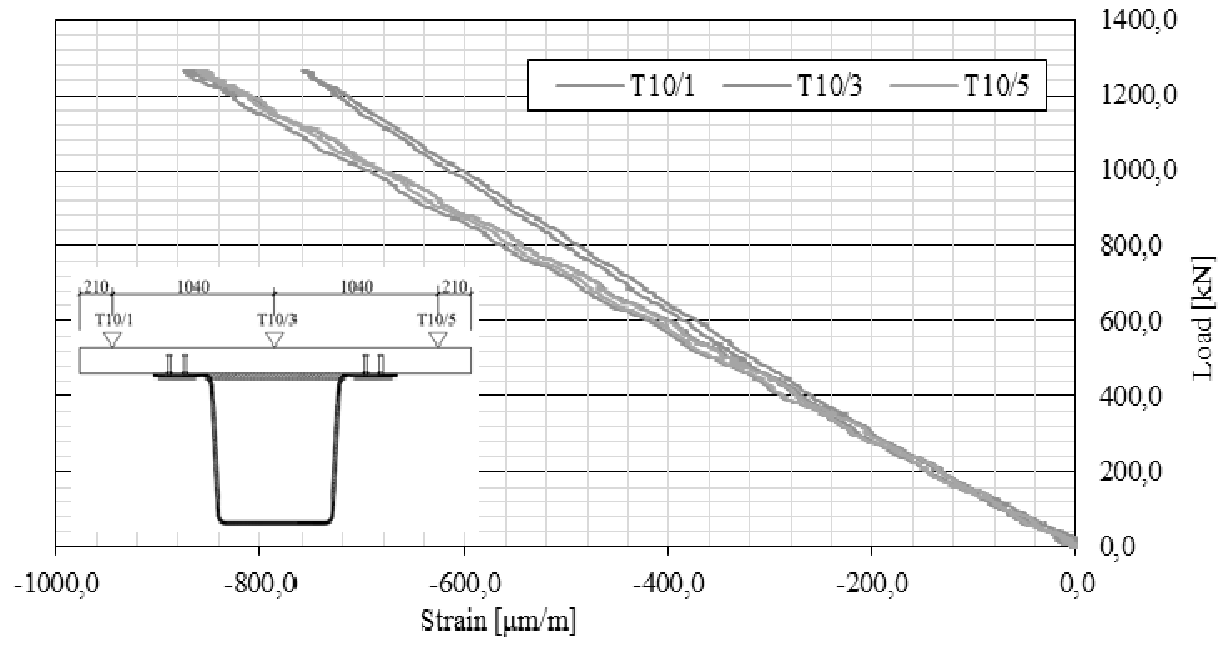

Fig.7. Concrete strain plots in the deck slab in mid-span cross-section

Rys. 7. Wykres odkształceń betonu w płycie pomostu w przekroju w środku rozpiętości

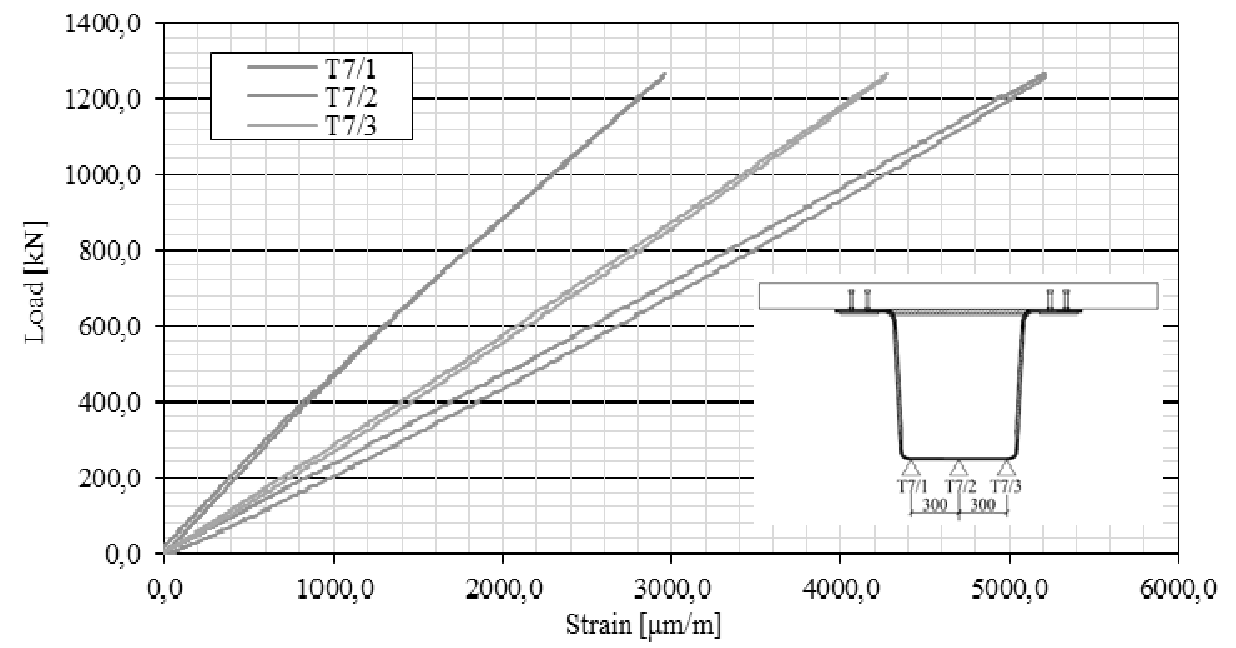

Fig.8. FRP strain plots in the bottom flange in mid-span cross-section

Rys. 8. Wykres odkształceń FRP w pasie dolnym w przekroju w środku rozpiętości

Under maximum load of $1260,0 \mathrm{kN}(2 \times 630,0 \mathrm{kN})$ the tested girder had no global destruction. However, during loading in the last stage several local damages could be seen in the form of:

- local fiber delamination in both flanges and in transition zone between web and upper flange (Fig.9 and 10); 

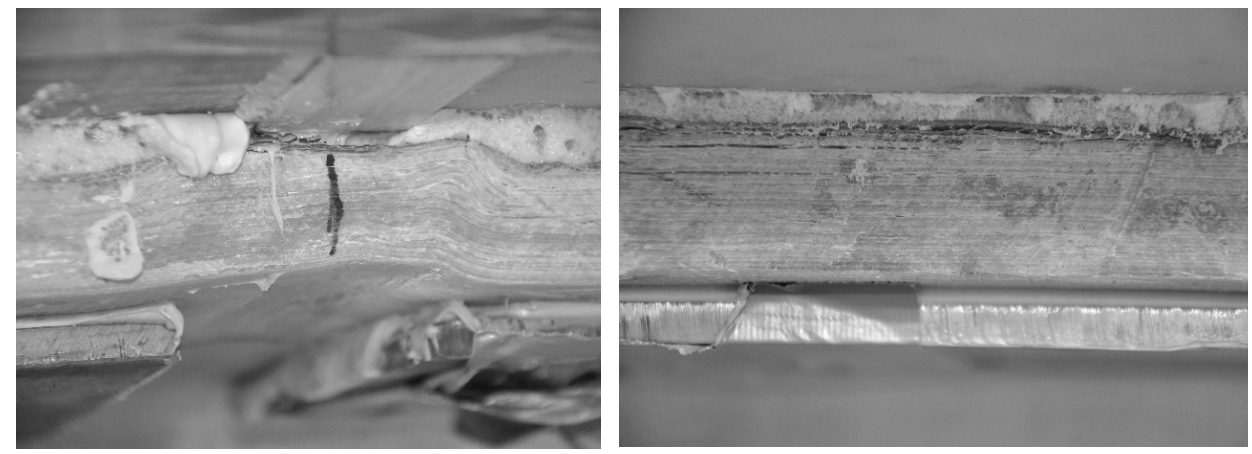

Fig.9. Delamination of the upper flange in the middle of the span (the location of structural notch in the production stage of the girder)

Rys. 9. Rozwarstwienie pasa górnego w środku rozpiętości (lokalizacja strukturalnego karbu powstałego w fazie produkcji dźwigara)
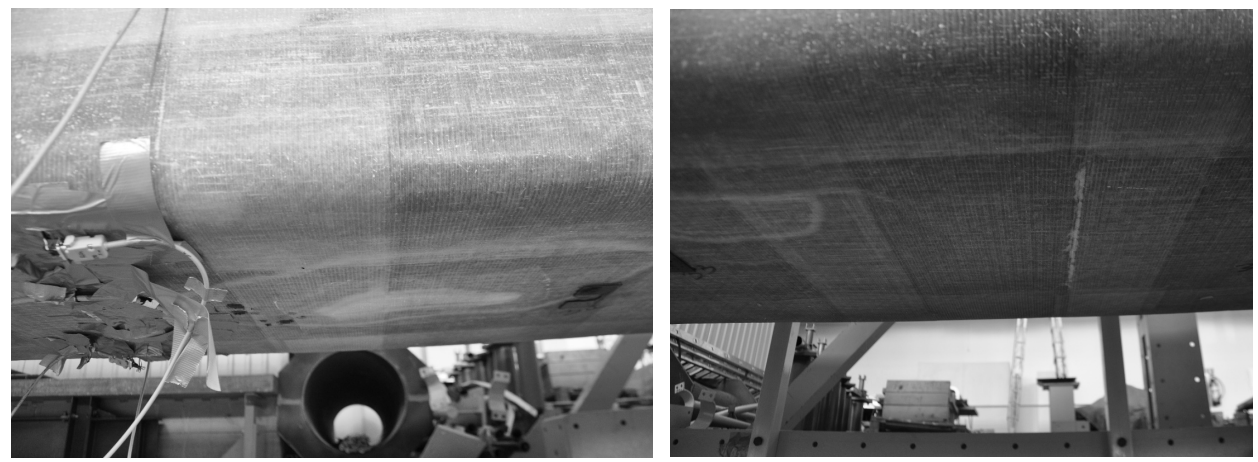

Fig.10. Delamination and scratch of the bottom flange laminate under the load point of the testing machine

Rys. 10. Rozwarstwienie i zarysowanie pasa dolnego zlokalizowane pod punktem przyłożenia obciążenia z siłownika

- failure of the epoxy adhesive, joining steel plates of shear studs with the upper flange (Fig.11);

- increasing local permanent deformation of the transition zone between the bottom flange and the web which formed during the production of FRP beam (Fig. 11);

- $\quad$ scratch the laminate in the bottom flange.

Most of these local failures was due to structural notches in FRP material. 

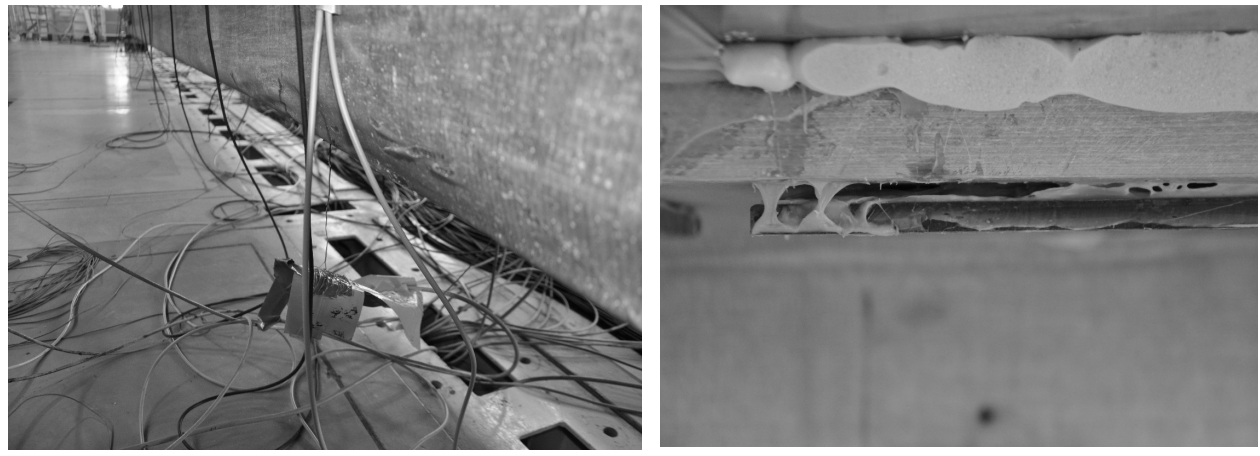

Fig.11. Increasing permanent deformation (the location of structural notch in the production stage of the girder) at the transition zone between the bottom flange and web in the middle of the span (left) and the failure of epoxy glue connecting upper flange and steel plate of shear studs

Rys. 11. Wzrost trwałych deformacji (lokalizacja strukturalnego karbu powstałego w fazie produkcji dźwigara) w strefie przejściowej między dolnym pasem a środnikiem w środku rozpiętości dźwigara (po lewej) i zniszczenie kleju epoksydowego łączącego górny pas z stalową blachą łączników zespalających

The FRP/RC hybrid system behaved linearly until the applied total research load of $1260 \mathrm{kN}$ (Fig. 6, 7, 8) and no residual displacement was observed after unloading (Fig.12). Permanent deformations arising during the production of FRP beam not adversely affect the behaved linearly of the FRP/RC hybrid girder.

Under the maximum load $(1260 \mathrm{kN})$ the maximum strain of the bottom flange was equal 5,209\%, which corresponds to the tension stresses of $603 \mathrm{MPa}$ in the carbon laminate and $219,5 \mathrm{MPa}$ in glass laminate oriented $0^{\circ}$ in the direction of the longitudinal axis of the beam. The maximum stress of the carbon laminate was $52,6 \%$, while the glass laminate $25,7 \%$ of the characteristic strength of individual laminates according to Table 3 . The concrete slab deck was not scratched under the load of $1260 \mathrm{kN}$. It should be noted that the girder reached the load-bearing capacity at the maximum range of actuators testing machine without undergoing the global destruction. The maximum girder's capacity established in the test (in terms of bending moment) was $\mathrm{M}_{\mathrm{n}}=5922,0 \mathrm{kNm}$, which is $323 \%$ of the characteristic bending moment on which the girder was designed. 


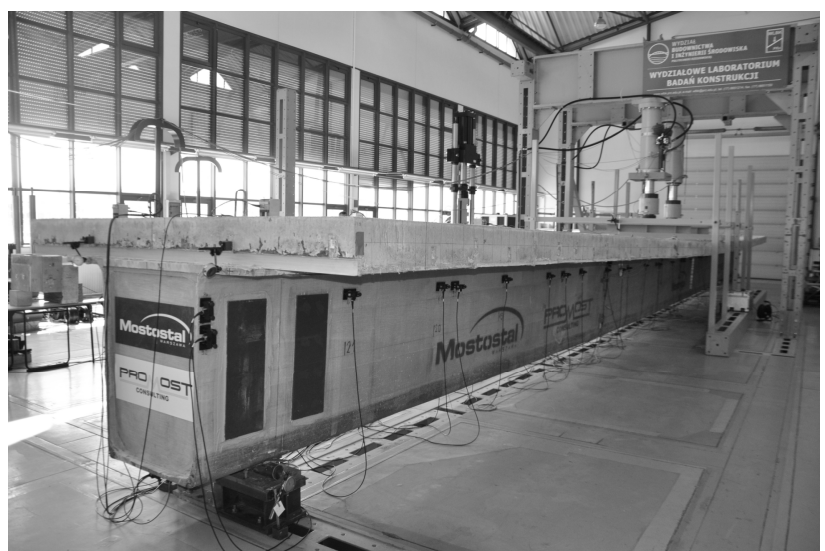

Fig.12. Global behavior of the girder under maximum load $(1260 \mathrm{kN})$

Rys. 12. Ogólne zachowanie się dźwigara przy maksymalnym obciążeniu (1260 kN)

\section{FEM model and evaluation of general behavior}

The numerical study was conducted for the girder under static tests with the use of the FEM code Sofistik 2014 (Fig. 13). Eight-node solid elements, with three degrees of freedom at each node were used for the concrete deck and concrete support zones of the girder. Four-node shell elements with 10 individual layers were used for the modelling of FRP beam. All elements were given characteristic of the material as shown in Table 1 and 2. The FEM model consisted of 8999 nodes which described 5130 shell elements and 2029 solid elements.
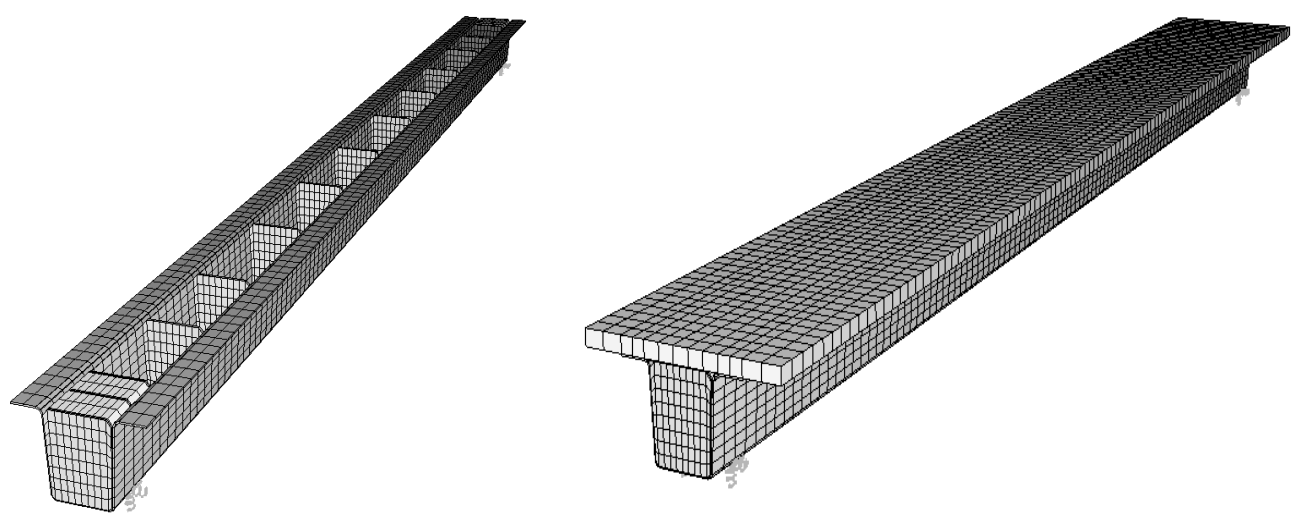

Fig.13. Visualization of the FEM numerical models: FRP beam (left) and FRP/RC girder (right) Rys. 13. Wizualizacja modelu numerycznego MES: belki FRP (po lewej) i dźwigara FRP/RC (po prawej) 
Comparison of the numerical FEM results with the experimental results is shown by the force/strain and the force/displacement plots (Fig. 14 and 15).

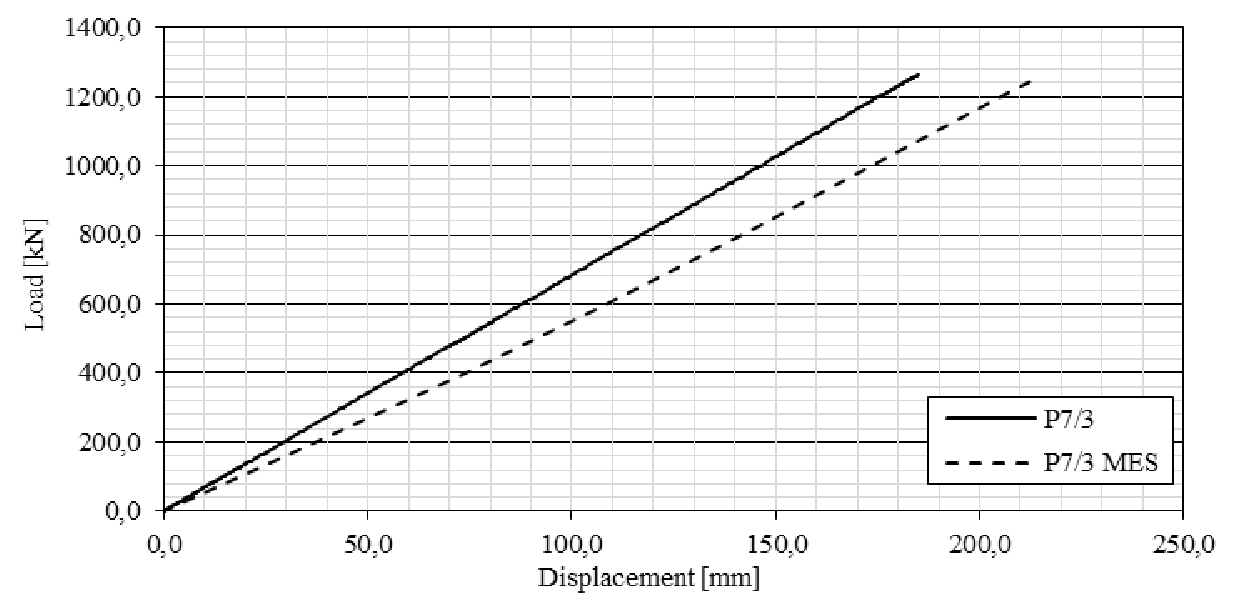

Fig. 14. Comparison of experimental and FEM displacement at the point $\mathrm{P} 7 / 3$

Rys. 14. Porównanie przemieszczenia w punkcie P7/3 otrzymanych z badań i modelu MES

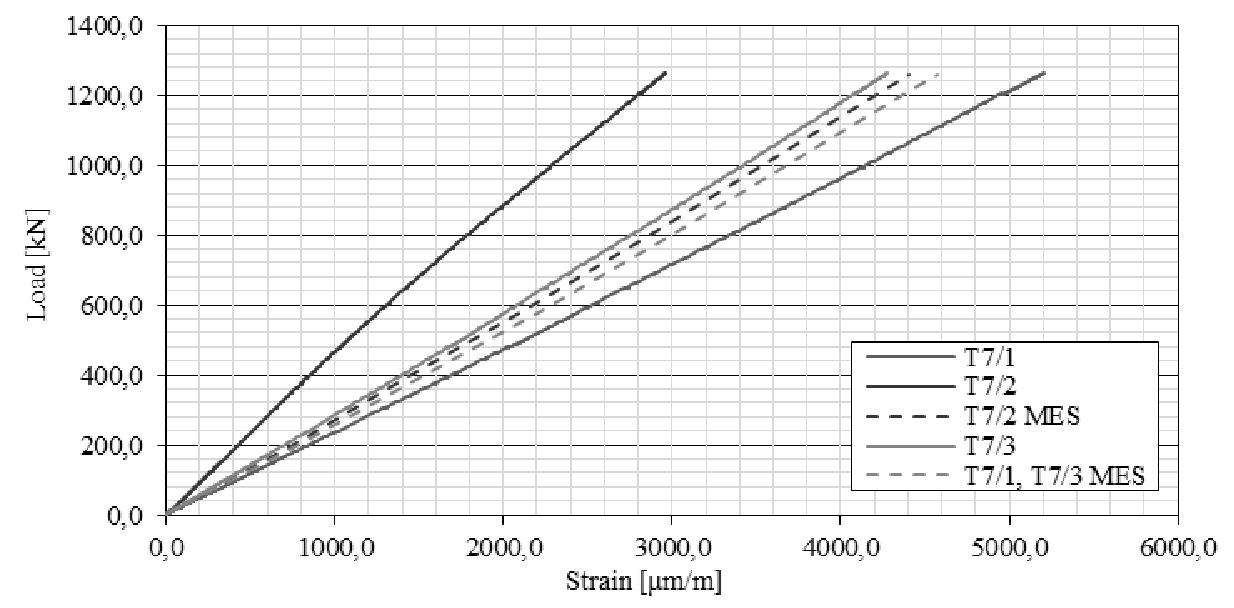

Fig.15. Comparison of experimental and FEM strains at the points T7/1-3

Rys. 15. Porównanie odkształcenia w punkcie T7/1-3 otrzymanych z badań i modelu MES

The comparison of experimental and theoretical (FEM) results showed acceptable accuracy of the numerical model of approximately $86 \%$ at the maximum load level and much less on the design load level. This result validated the FEM model as the reliable design tool for analyzing the actual bridge on design stage. However, a computer program Sofistik have no possibilities 
to model the inner structure of FRP. Because of the large number of FRP layers, the middle layers had to be replaced with a uniform material with average parameters resulting from the characteristic substitutable materials. It decreased the accuracy of the FEM model behavior in comparison to the actual FRP/RC girder. For the scientific purposes more sophisticated FEM code should be used with the inner procedures dedicated to model FRP composite structures and their behavior under loading.

\section{Conclusions}

The paper describes the results of studies determining the behavior of the FRP/RC hybrid girder under static tests. Analyzing the main findings of research it should be stated that the girder was not globally destroyed under the total load of $1260 \mathrm{kN}$, i.e. its global coefficient of safety could be estimated as more than 3,0. It is quite good result for this pioneering and innovating structure ensuring the safety and reliability of the bridge made of four such girders will be high enough. In the entire load range the girder worked perfectly linearly. When compared to the calculated design load, the ultimate load could be estimated as approximately 2,2 times greater and this indicates the original design was very conservative and there is a wide range of optimization with the help of validated FEM model. The proposed numerical model showed acceptable accuracy of approximately $86 \%$. In order to increase the accuracy of the FEM model, the analysis of composite material in a more advanced FEM program, which is dedicated to this type of material, should be undertaken.

This research project is supported by the National Centre of Research and Development in the frame of DEMONSTATOR+ programme, the project title: "Com-Bridge: Innovative road bridge with FRP composites" (No. UODDEM-1-041-/001).

\section{Bibliography}

[1] Chen Y., Ziehl P.H., Harrison K.W. Experimental characterization and optimization of hybrid FRP/RC bridge superstructure system. Journal of Bridge Engineering, Vol.14, Issue 1, pp. 45-54, 2009.

[2] CSA STANDARDS S806-12. Design and construction of building structures with fibre - reinforced polymers. 2012.

[3] Deskovic N., Triantafillou T.C., Meier U. Innovative design of FRP combined with concrete: short-term behavior. Journal of Structural Engineering, Vol. 121, No.7, pp.1069-1078, 1995.

[4] Hillman J.R., Murray T.M. Innovative floor systems for steel framed buildings. Mixed structures, including new materials. In: Proceedings of IABSE Symposium, Brussels, Belgium, IABSE, Zurich, vol. 60, p. 672-675, 1990.

[5] Mirmiran A., Shahawy M., Beitleman T. Slenderness limit for hybrid FRP-concrete columns. Journal of Composites for Construction, Vol.5, No.1, pp.26-34, 2001. 
[6] Keller T. Use of fibre reinforced polymers in bridge construction, Structural Engineering Documents, No. 7, IABSE, Zurich, Switzerland. 2003.

[7] Kitane Y., Aref A. Static and fatigue testing of hybrid fiber-reinforced polymerconcrete bridge superstructure. Journal of Composites for Construction, Vol.8, No.2, pp.182-190, 2004.

[8] Van Erp G.M. Design and analysis of fibre composite beams for civil engineering applications. Proceedings of the 1st ACUN International Composites Conference, Composites: Innovations and Structural Applications. Sydney, pp.229-238, 1999.

[9] Siwowski T., Kaleta D., Kulpa M. The design of the first Polish road bridge made of FRP composites. Inżynieria i Budownictwo, Vol. LXXI, No. 9, pp. 465-470, 2015 (in Polish).

[10] Siwowski T., Poneta P., Kulpa M. Development and research on the innovative FRP girder for bridge application. The proceedings of $37^{\text {th }}$ IABSE Symposium "Engineering for Progress, Nature and People", Madrid, IABSE Report Vol.102, pp. 2239-2246, 2014.

\section{BADANIA HYBRYDOWEGO KOMPOZYT FRP - BETON DŹWIGARA MOSTOWEGO}

\section{Streszczenie}

Mosty hybrydowe składają się z kompozytów FRP i betonu, w który dźwigary FRP pracują wspólnie z płytą RC pomostu. Most hybrydowy charakteryzuje się między innymi dużą sztywnością i nośnością, doskonała trwałość, a co z tym związane niskimi kosztami utrzymania. W ostatnich latach powstało kilka mostów hybrydowych w Hiszpanii i USA. Budowa pierwszego w Polsce nowatorskiego hybrydowego mostu drogowego jest planowana jako część projektu badawczo-rozwojowy ComBridge. Będzie to również jeden z największy (pod względem rozpiętości przęsła) tego rodzaju most na świecie. Most będzie budowany z dźwigarów skrzynkowych FRP wytworzonych $\mathrm{w}$ procesie zalewania, oraz płytę pomostu $\mathrm{z}$ betonu lekkiego, zbrojonego prętami GFRP. Płyta będzie zespolona $z$ dźwigarem za pomocą specjalnych sworzni ścinanych i przyczepności. Politechnika Rzeszowska jako partner projekcie badawczo-rozwojowym, jest odpowiedzialna za badania doświadczalne w laboratorium, łączników dźwigara z płytą, płyty zbrojonej prętami GFRP, oraz całego dźwigara hybrydowy FRP/RC w naturalnej skali. Po wykonaniu mostu, Politechnika Rzeszowska przeprowadzi próby pełnej konstrukcji. Celem artykułu jest opisywanie badań statycznych hybrydowego dźwigara mostowego FRP/RC w skali naturalnej, oraz przedstawienie wyników badań pod względem jego ogólnego zachowania, nośność, rodzaj zniszczenia i sprawdzenie poprawności modelu numerycznego MES.

Słowa kluczowe: dźwigar kompozytowy FRP, płyta z betonu lekkiego. Beton zbrojony prętami GFRP, most hybrydowy FRP/RC, badania statyczne w skali naturalnej 